\title{
Psikolojimiz ve Beyin Sağlığımızda Beslenmenin Önemi
}

\author{
The Importance of Nutrition in Our Psychology and Brain Health
}

\section{Prof. Dr. Türkan Kutluay Merdol ${ }^{1}$}

\section{Gíriş}

Yaşamı sağlıklı sürdürmek için sadece fizyolojik gereksinimleri karşlayacak besinlerin tüketilmesi yeterli değildir. Bu gereksinim yanında, genel olarak psikolojik ve sosyolojik olarak gruplanan pek çok başka gereksinimlerimiz vardır. Yeni koronavirüs hastalığı-19 (COVID-19) salgını nedeniyle, genel sağlığın, özellikle de bağışıklık sisteminin güçlü olmasının ne kadar önemli olduğunu acı deneyimlerle yeniden hatırladık. Bu süreç içinde, özellikle sosyal medya aracılığı ile bireylerin pek çok ruh sağlığı sorunu ile karşı karşıya kaldığını sıklıkla duymaya başladık. Bu nedenle bu editöryal yazımda hem psikolojimizin hem de beyin sağlığımızın korunması ve güçlenmesinde, yeterli, dengeli ve sağlıklı (YDS) beslenmenin önemine dikkat çekmek istedim.

\section{Beyin Hangi Besin Ögeleri ile Çalışır?}

İnsan beyni, merkezi sinir sisteminin en önemli organı olarak, yüksek bir metabolik hızla çalıştığından, kullanması gereken çok önemli ögeler vardır. Bu ögeler; esansiyel amino asitler, esansiyel yağ asitleri (özellikle omega 3), glikoz, A, C, D, E ve $\mathrm{B}_{1}, \mathrm{~B}_{6}$ (pridoksin), $\mathrm{B}_{12}$, folik asit ve kolin gibi $\mathrm{B}$ grubu vitaminleri, demir, çinko, bakır, selenyum, kalsiyum, fosfor, potasyum ve magnezyum gibi mineraller olarak sıralanabilir. Bedenimiz, dıştan ve içten gelen uyaranlara karşı çeşitli tepkiler verir. Bu tepkiler; baş ağrısı, kalp çarpıntısı, mide bulantısı, sinirlenme, terleme, esneme, hapşırma, geğirme, hıçkırık, ishal ya da kabızlık, kan basıncında değişme ve benzeri tepkilerdir. Beyin, bu tepkilerin kontrolünün etkin bir şekilde yerine getirilebilmesinde görev alan enzim ve hormonların devreye girmesi için bir seri reaksiyon başlatır. $\mathrm{Bu}$ reaksiyonlarla tepkilerin bedene zarar vermesini önlerken, yukarıda saydığımız ögeleri kullanır. Bu görev için ögelerin yeterli ya da yetersiz olması durumunda, tepkilerin bedene yaptığı etkiler de olumlu ya da olumsuz olur. Tepkiler kontrole alınamaz ve süresi uzarsa, vücut direncinde azalma, beden ağırlığında artma ya da azalma, sistemik hastalık (diyabet, kalp-damar hastalıkları, kanser vb.) gelişimi, sosyal aktivitede azalma, depresyon ve demans gelişebilir. $\mathrm{Bu}$ tepkilerin kontrolü ağırlıkları normal değerlerin altında (zayıf) ya da üstünde (şişman) olanlar için daha zordur. Ayrıca beden; zararları pek çok çalışma ile açıkça ortaya konulmuş bulunan, sigara, alkol ve gereğinden fazla ilaç kullanımında bu ögelerin birçoğunu daha fazla kullanmak zorunda kalır. Aynı durum, stres yaratan durumlarla savaşırken de yaşanır. Örneğin sigara içenlerde C vitamini gereksinimi, sigara içmeyenlere göre iki kat daha fazladır. Stres durumunda vitaminlerin yaklaşık \%32'sinin harcandlğı bilinmektedir. Alkol tüketiminde, vücutta fazla harcanan tiamin ( $B_{1}$ vitamini) yetmezliğine bağll olarak kişide tenkitlere duyarlılık, kendini kontrolde zorlanma ve tüketimin arttığı durumlarda saldırgan davranışlar gelişebilir. Bipolar bozukluğu olanlarda kanda yüksek seyreden vanadyum elementinin yapacağı hasara karşı korunmak amacıyla, tedavide

1. Atılım Üniversitesi, Sağllk Bilimleri Fakültesi, Beslenme ve Diyetetik Bölümü, Ankara, Türkiye • E-posta: info@beslenmevediyetdergisi.org (1) https://orcid.org/0000-0002-0783-947X 
yüksek miktarda C vitamini kullanılır. Enfeksiyöz hastalıklarda da hastanın genel durumuna göre C vitamini tedavi amacıyla kullanıldığında 2-4 grama çıkarılabilmektedir, oysa günlük ihtiyaç yaşlara göre farklılık gösterse de 60-100 mg kadardır. Bu nedenle, antioksidan özelliği yüksek olan C vitamini anti stres vitamini olarak da bilinir. Diğer taraftan, tedavi dozu sadece hastanın genel durumunu düzeltmek için yükseltilen bir değerdir, hastalık söz konusu değilse yüksek miktarda kullanılan C vitamininin, böbrek taşı sorunu olanlar için tehlikeli olabileceği unutulmamalıdır.

Duygu durumunun kontrolünde merkezi sinir sistemimizin çok önemli görevler üstlendiğini biliyoruz. Bu sistemi oluşturan hücreler arası mesaj iletiminde nörotransmitter olarak adlandırılan moleküller yer alır. En önemli nörotransmitterler serotonin, dopamin, norepinefrin ve asetilkolindir. Nörotransmitterlerin az ya da çok yapılmalarının iştah, düşünce, duygu ve davranış üzerinde olumlu ya da olumsuz etkiler yarattığı bilinmektedir. Örneğin yüksek karbonhidratlı besinlerle serotonin miktarının artmasına bağlı olarak kusma ve psişik bozukluk olabileceği gibi yetersiz kalmasına bağlı olarak da baş ağrısı, şekerli besin yeme arzusu, uyku düzensizlikleri, halsizlik, ağrı duyarlılığı, agresif ve depresif davranışlar ortaya çıkabilmektedir. Bir diğer nörotransmitter olan asetilkolinin uyanık kalma, hafıza güçlendirme, bilişsel yetenekte artma gibi fonksiyonları vardır. Asetilkolin yapımında fosfolipidler yer alır ve fosfolipidler lesitinin başlıca unsurlarından biridir. Lesitin, yağın vücutta taşınmasını kolaylaştıran madde olarak tanımlanır, çünkü yağın su içinde dağılmasında aracı bir rol oynar. Lesitin, besinler içinde en çok yumurtada bulunur. Yumurta, lesitin dışında, demir başta olmak üzere, A vitamini, D vitamini ve diğer pek çok besin ögesi için önemli bir kaynaktır ve protein kalitesi bakımından besinler içinde birinci sırada yer alır. Son yıllarda yapılan araştırmalarla, antioksidan özellikleri açısından öne çıkan lutein ve zeaksantin gibi karotenoidler açısından da zengin olduğu anlaşılmıştır. Luteinin göz sağlığında önemli rolü olduğu bilinmektedir. Asetilkolinin Alzheimer hastalarında düşük düzeyde seyrettiği bildirilmektedir. $\mathrm{Bu}$ bağlamda, özellikle yaşlı kişilerin diyetlerinde en önemli besin olarak yumurta mutlaka bulunmalıdır. Dopamin ve norepinefrin de hafıza, dikkat ve karar vermede görevleri olan nörotransmitterlerdir. Yapılarında tirozin amino asidi bulunur. Tirozin, fenilalanin amino asidinden yapılan esansiyel olmayan bir amino asittir. Yeterli, dengeli ve sağlıklı bir diyetle yeterli miktarlarda alınabilir. Ancak günümüzde, kişilerin YDS’den uzak beslenmeleri nedeniyle, firmalar tirozin tabletleri yapıp satmaya başlamışlardır. $\mathrm{Bu}$ tür tabletlerin kullanımının kontrole alınmadığı durumlarda, tirozin fazlalığı bazı ilaçların biyoyararlılığını azaltıcı etki yaratabilir. Tirozin; tavuk, hindi, balık, süt, yoğurt ve peynir gibi ürünlerde bol miktarda bulunduğundan, diyette bu besinlerin yer alması en doğru tüketim şeklidir. Diyette demir yetersizliği olduğunda yapımları azalan bu nörotransmitterlerin, diyette protein fazla olduğunda yapımlarının arttığı da unutulmamalıdır. Genel olarak nörotransmitterlerin, nöronlar arasında iletiminde kalsiyum da çok önemli bir yer tutar. Özellikle yaşlllarda yeterli miktarlarda kalsiyum tüketimi hafiza kayıplarını önlemede çok yararlı olduğundan süt, yoğurt, peynir gibi zengin kalsiyum kaynaklarının ortalama üç porsiyon tüketilmesi ihmal edilmemelidir. Ancak, Türkiye'de yapılan araştırmalar, yaşlılarda bu guruptaki besinlerin tüketiminin çok düşük olduğunu gösterdiğinden yaşlıların bu guruptan günde en az bir porsiyon almaya özel göstermesi çok önemlidir.

Beyin hücrelerinin kullandığı diğer önemli besin ögeleri omega 3 (n-3) ve omega 6 (n-6) yağ asitleridir. Bu yağ asitleri fosfolipidlerin yapısında yer aldığından birbirlerine göre oranları çok önemlidir. Bu nedenle, diyetle alınacak n-6:n-3 oranının 5:1-10:1 arasında olması önerilmektedir. Batı tarzı denilen, yağ, şeker, tuz oranı yüksek diyetlerde bu oran 20:1-25:1'e kadar yükselebilmektedir. Omega 3 yağ asitleri aynı zamanda nöronlar arası iletimde de rol almaktadır. Doymuş yağ ve trans yağ (margarinler gibi) ağırlıklı besinlerin tüketilmesi, nörotransmitterlerin mesaj iletimi etkinliği üzerinde olumsuz etki yaratmaktadır. 
Merkezi sinir sistemi hücreleri fonksiyonlarında önemli vitaminlerden biri de D vitaminidir. Yağda eriyen D vitamini, başta kalsiyum olmak üzere mineral homeostazındaki rolü nedeniyle nörosteroid kabul edilmektedir. D vitamini, birçok genin ekspresyonunda, düzenleyici olarak görev yapar. D vitamini yetmezliğinde, depresyona kadar giden ruhsal sorunlar oluştuğunu gösteren çalışmalar bulunmaktadır. D vitamini, folik asit ve demir yetersizliğinin şizofrenide önemli bir etken olduğu bildirilmektedir. Ancak fazlalığının toksik etki yarattığı da bilinmektedir.

Unutulmaması gereken bir diğer önemli nokta da bilinen her vitamin ve mineralin yetmezliği oluştuğunda, vücutta pek çok olumsuz belirtilerin baş göstermesidir. Örneğin A vitamini yetmezliğinde, karanlığa adaptasyon güçlüğü, yorgunluk ve anemi, C vitamini eksikliği olduğunda halsizlik, yorgunluk, içe kapanıklık, depresyon, demir yetmezliğinde anemi, yorgunluk, baş ağrısı, dopamin geçişinde azalma, kalsiyum yetmezliğinde, baş dönmesi, konfüzyon, tetani, tansiyon değişmesi, magnezyum yetmezliğinde, halsizlik, aşırı duyarlılık, aritmi, selenyum yetmezliğinde anksiyete ve depresyon gelişebilmektedir.

Besinlerin içinde bulunan besin ögelerinin izolasyonu ve miktarları ancak 20. yüzyıl başlarında saptanmaya başladığından ve içlerinde sayısız vitamin ve mineral barındırdıklarından, 21. yüzyıla kadar bitkilerin pek çoğunda bulunan ve fitokimyasallar olarak tanımlanan pek çok başka maddenin de var olduğu bilinmiyordu. Son iki dekadda bu maddelerin neler olduğu ve besinlerde ne miktarlarda bulunduğu yönünde çalışmalar da artmış ve genel olarak antioksidan özellik taşıdıkları bilinen pek çok madde listelenmiştir. Bunların başında, kateşin, resveratrol, lutein, zeaksantin, antosiyanin, kuersetin ve likopen gibi flavanoid ve karotenoid grubunda yer alan maddeler vardır. Bu maddelerin etkileri üzerinde yapılan in vitro çalışmalar, hücrede artan oksidatif strese bağlı olarak oluşabilecek hasarı önlemeye yardımcı olabildiklerini göstermektedir. Piyasa bu çalışmalar paralelinde bu ögeleri içeren tabletler ve formülalarla dolmaya başlamıştır. Ancak bu ögelerin in vivo çalışmaları, henüz güvenirliliği yüksek dergilerde yeterince yayınlanmadığından ve rutin kan tetkiklerinde bu ögelerin değerlerine bakılmadığından kontrolsüz kullanılmaları doğru değildir.

Beden sağlığı ve beyin sağlığının, bağırsakların sağlığı ile de yakından ilgili olduğunu da unutmamak gerekir. Fazla yağlı, şekerli ve tuzlu besinlerin bağırsak florasını bozduğu bilinmektedir. Bağırsak florasının pek çok işlevi vardır. Bunların başında, vitamin ve yağ asidi sentezleme, toksinleri hasara uğratma, patojen bakteri kolonileşmesini önleme ve immün sistem cevabını uyarma sayllabilir. Yetersiz, dengesiz ve sağlıksız beslenme, sigara, alkol tüketimi ve stres bağırsak florasını bozan etmenlerdir. Bağırsak bu etkiler altında, ishal ya da kabızlık olarak tepki verir. Her iki durum da tedavi edilmezse sağlığın bozulmasına yol açar. İshalde ve kabızlıkta özel diyet gerektiği bilinen bir gerçektir.

Bir çocuğun sağlığı, annenin gebelik döneminde YDS beslenmesi ile doğrudan ilişkilidir. Anne gebelik döneminde yetersiz, dengesiz ve sağlıksız beslenirse gebelik sonrasında post partum depresyon olarak adlandırılan tablonun ortaya çıkması söz konusu olabilir. Post partum depresyonun oluşmasinda n-3, n-6 yağ asitleri, B kompleks vitaminleri özellikle $B_{12}$ ve folik asit, $\mathrm{D}$ vitamini ve demir, çinko ve selenyum gibi minerallerin yetersizliğinin rolü olduğu da araştırmalarla gösterilmiştir. Gebelik döneminde YDS beslenme sinir sistemi sağlığının korunması ve enflamasyonun önlenmesinde en temel faktörlerden biridir. Elbette bebeğin fetal yaşamının son üç aylık dönemi ve doğumdan sonraki ilk ayları beyin ve sinir sisteminin gelişiminde en önemli dönem olduğundan, yaşamın bu dönemi altın değerindeki dönem olarak tanımlanır. Çocuğun iki yaşına kadar olan dönemde, beyin gelişiminin optimal düzeyde görev yapabilmesi için YDS beslenmesi hayati bir önem taşır. 
Yukarıda anlatılan bilgiler doğrultusunda YDS beslenmenin, özellikle de COVID-19 gibi enfeksiyöz hastalıklarda, ne kadar önemli olduğu açlktır. YDS beslenmede temel taşlar, dört gruba ayrlarak sinıflandırılan besin grupları içinde yer alan besinlerle atılır. Besin grupları içinde de birinci sırada; et, tavuk, balık, yumurta, kurubaklagiller ve ceviz, findık, fıstık gibi yağlı tohumların ve kabuklu yemişlerin yer aldığı grup gelir. Sinir hücreleri başta olmak üzere, hücrelerin yapı taşı olan amino asitler, proteinli besinlerle sağlanır. Bitkisel kaynaklardan gelen proteinler, esansiyel amino asitler bakımindan hayvansal kaynaklı proteinler kadar zengin olmadıklarından biyoyararlılıkları daha düşüktür. Bu nedenle hayvansal besinlerle birlikte alınmadıklarında işlevlerini tam olarak yerine getiremezler. İkinci grup besinler; süt, yoğurt ve peynirin, üçüncü grup; meyve ve sebzelerin, dördüncü grup da ekmek ve tahılların yer aldığı gruplardır. $\mathrm{Bu}$ gruplardan, bireysel ihtiyaçlara göre alınacak miktarların belirlenmesi kadar, beynimizin bütün gece hücre onarımı yönetmesi sirasında kullanılan ögelerin iyi bir kahvaltı ile yerine konması da çok önemlidir. Gece boyu nefes alan bedenimiz susuz da kalabilir. Bu nedenle, özellikle yetişkinler ve yaşlılar için sabah içilecek bir bardak su ile güne başlamak ve sonrasında YDS bir kahvaltı yapmak sağlıklı yaşam için önemli ve çok gerekli adımlardır.

\section{SONUÇ}

Akıl sağlığı sorunları, engelliliğin ön önemli nedenidir. Bu sorunları önlemek için pek çok ilaç desteği kullanılmaktadır. Bu destekler hastalığın tedavisinde çoğunlukla yetersiz kalmakta, ayrıca vücutta meydana gelen yan etkileri nedeniyle de hastanın tedavi başarısı oldukça düşük olmaktadır. Oysa etkili bir psikolojik destekle birlikte, hastaya özel olarak düzenlenmiş YDS programı ve yine hastaya özel hazırlanmış egzersiz desteği ile akıl sağlığını ilgilendiren tedavilerin başarısını gösteren pek çok örnek vardır. YDS beslenmenin temel özelliklerini, her yaş grubuna göre günlük alınacak miktarların ne kadar olduğunu, bu besinlerin ne zaman tüketilmesi gerektiğini, saklama, hazırlama ve pişirmede nelere dikkat edilmesi gerektiğini en iyi beslenme ve diyet konusunda yetkili tek uzman olan diyetisyenlerin bildiği unutulmamalı ve YDS beslenmeyi öğrenmek için diyetisyenlerden yardım alınmalıdır.

\section{KAYNAKLAR}

1. Bakoyiannis I, Daskalopoulou A, Pergialiotis V, Perrea D. Phytochemicals and cognitive health: Are flavonoids doing the trick?. Biomedicine \&Pharmacotherapy. 2019;109:1488-9.

2. Geng C, Shaikh AS, Han W, Chen D, Guo Y, Jiang P. Vitamin D and depression:mechanism, determination and application. Asia Pac J Clin Nutr. 2019;28(4):689-5.

3. Georgieff M, Ramel SE, Cusick SE. Nutritional influences on brain development. Acta Paediatr. 2018;107(8):131011.

4. Kaplan BJ, Crawford SG, Field CJ. Simpsons JS. Vitamins, minerals and mood. Psycol Bull. 2007;133:747-13.

5. McGrath J, Brown A, Clair D. Prevention and Schizophrenia-the role of dietary factors. Schizophrenia Bulletin. 2011;37:2:272-9.

6. Moore K, Guhnes CF, Ward M, Hoey L, Mcnulty H. Diet, nutrition and the ageing brain: current evidence and new directions. Proc Nutr Soc. 2018;77(2):152-11.

7. Psaltopoulou T, Sergentanis TN, Panagiotakos DB, Sergentanis JN, Kosti R, Scarmeas N. Mediterrannean diet, stroke, cognitive impairment, and depression: Meta analysis. Ann Neurol. 2013;74:580-11.

8. Reis LC, Hibbelu JR. Cultural symbolism of fish and the psychotropic properties of omega 3 fatty acids. Protoglandins Leukot Essent Fatty acids. 2006;75(45):227-9.

9. Sudhof TC. Calcium control of neurotransmitter release. Cold Spring Harb Perspect Biol. 2012;4(1):a011353.

10. Trujillo J, Vieira MC; Lepsch J, Rebelo F, Poston L, Pasupathy D. A systematic review of the associations between maternal nutritional biomarkers and depression and/or anxiety during pregnancy and postpartum. J Affect Disord. 2018;232:185-18.

11. Ward RJ, Zucca FA, Duyn JH, Crichton RR, Zecca L. The role of iron in brain ageing andneurodegenerative disorders. Lancet Neurol. 2014;13(10):1045-15. 